\title{
Punishing Core Crimes in Ethiopia: Analysis of the Domestic Practice in Light of and in Comparison, with Sentencing Practices at the UNICTs and the ICC
}

\author{
Tadesse Simie Metekia
}

Law Faculty, Rijksuniversiteit Groningen, Groningen, The Netherlands t.s.metekia@rug.nl

\begin{abstract}
Between 1992 and 2010, Ethiopian courts prosecuted over five thousand people for the core crimes of genocide and war crimes perpetrated in Ethiopia since 1974. The vast majority of the defendants were convicted and sentenced to a range of penalties applicable under Ethiopian law. This article examines the manner in which Ethiopian courts have punished core crimes. It analyses the domestic law and practice in light of and in comparison with the sentencing practice in the UNICTs and the ICC. The article also discusses whether Ethiopian law and practice have treated the punishment of core crimes differently than the punishment of domestic crimes.
\end{abstract}

\section{Keywords}

core crimes - death penalty - discretion - double counting - initial penalty - mass trials - retribution - special aggravating and mitigating factors

\section{Introduction}

Ethiopia is not new to prosecuting and punishing core crimes. ${ }^{1}$ The Dergue trials (1992-2010), known colloquially as the Red-Terror trials, denote the first instance of prosecution of core crimes (political genocide and war crimes) in

1 In relation to Ethiopian trials, the expression 'core crimes' is used in this article to refer to genocide and war crimes only. Crimes against humanity and aggression are not listed as criminal offences in Ethiopian law.

(C) TADESSE SIMIE METEKIA, 2019 | DOI 10.1163/15718123-01901007

This is an open access article distributed under the terms of the prevailing CC-BY-NC license at the time of publication. 
Ethiopia as well as in Africa. These trials commenced after the Transitional Government of Ethiopia (1991-1995) had established in 1992 the Special Prosecutor's Office (SPO) to prosecute mass atrocities perpetrated during the Dergue regime (1974-1991) due to violent political skirmishes and protracted civil wars. ${ }^{2}$

Besides the Dergue trials, Ethiopia prosecuted core crimes in: $(i)$ the AnuakNuwer trials (2004-2005), (ii) the CUD trials (2005-2008), and (iii) the OromoGumuz trials (2008-2010). The Anuak-Nuwer trials dealt with the prosecution of the genocidal killing of 32 South-Sudanese refugees identified as members of the Nuwer ethnic group by the perpetrators, security forces belonging to the Anuak ethnic group. ${ }^{3}$ In the CUD trials, members of an opposition coalition named Coalition for Unity and Democracy were prosecuted for an attempted genocide in relation to post-election conflict that erupted in the country in early $2005 .{ }^{4}$ The Oromo-Gumuz trials prosecuted individuals for a genocide committed in the context of an inter-ethnic conflict that took place in western Ethiopia in May 2008 between members of the Oromo and the Gumuz ethnic groups. ${ }^{5}$

Ethiopian courts have imposed various kinds of penalties on thousands of individuals found guilty of perpetrating core crimes. ${ }^{6}$ This article analyses the manner in which these trials have punished core crimes. It examines the Ethiopian law and practice on sentencing in light of and in comparison with that of the UNICTS (the ICTY and ICTR) and the ICC. In this respect, the justification for comparing the domestic and the international systems rests on the fact that both systems have functional equivalence in prosecuting and punishing core crimes. To provide for a comprehensive analysis of the Ethiopian practice, the article juxtaposes, when relevant, the punishment of core crimes with that of domestic crimes.

Accordingly, section 2 provides an overview of convictions and sentences imposed in the Ethiopian core crimes trials. Section 3 discusses the applicable laws and penalties. Section 4 focuses on sentencing rationales invoked in Ethiopian trials of core crimes and compares and contrasts them with the

2 Proclamation Establishing the Office of the Special Prosecutor: No. 22/1991, entered into force 8 August 1992, Articles 1 and 6. For a detailed historical context, see Teferra Haile-Selassie, The Ethiopian Revolution 1974-1991: From a Monarchical Autocracy to a Military Oligarchy (Routledge, London, 1997) 147-295.

3 See Federal Prosecutor v. Gure Uchala et al., FHC, File No. 31855.

4 Federal Prosecutor v. Hailu Shawul et al., F HC, File No. 43246/97.

5 See Prosecutor v. Tadesse Jewannie et al., FHC, File No. 70996.

6 See section 2 infra. 
purposes of punishment in the international arena. Section 5 makes a comparative analysis of the rules governing mitigation and aggravation of sentences. Section 6 discusses the issue of individualization of sentences and the totality principle in mass trial cases. Section 7 concludes the article by pointing out the significant aspects of the comparison.

\section{2 Overview of the Convictions and Sentences Imposed}

The above-mentioned four trials have prosecuted 5492 suspects for core crimes. In the Dergue trials, the spo indicted 5119 individuals. The Oromo-Gumuz trials prosecuted 276 defendants ${ }^{7}$ while the Anuak-Nuwer trials brought only 9 persons to justice. ${ }^{8}$ In the CUD trials, 88 individuals stood trial, all of whom were acquitted of genocide-related charges by the Federal High Court (FHC), which entered a conviction for treason instead. ${ }^{9}$

The Anuak-Nuwer trials found 3 of the 9 defendants guilty. ${ }^{10}$ In the OromoGumuz trials, 174 of 276 suspects were convicted. ${ }^{11}$ The Dergue trials entered a guilty verdict for 3583 of the 5119 defendants. ${ }^{12}$ On average, the conviction rate of the three trials stands at 69.5 percent, which means that 3760 of the 5404 suspects were convicted and punished.

As abridged in the following table, the penalty imposed on perpetrators of core crimes varies between 2 years of rigorous imprisonment ${ }^{13}$ to punishment by death. In the Dergue trials, $5^{2}$ death sentences, 182 life sentences, and 921 sentences of rigorous imprisonment from 15 to 25 years were imposed. In the Oromo-Gumuz trials, the FHC sentenced 7 individuals to death, 8 individuals to

$7 \quad$ See Federal Prosecutor v. Aliyu Yesufe et al., FHC (Indictment of 3 September 2008), File No. 7100o; pp. 1-8; Tadesse Jewannie et al. (Indictment of 3 September 2008), pp. 1-9; Federal Prosecutor v. Tesfaye Neno Loya et al., FHC (Indictment of 20 September 2008), File No. 74796 pp. $1-4$.

8 See Gure Uchala et al. (Indictment of 2 February 2004), pp. 1-2.

9 See Hailu Shawul et al. (Judgment of 30 March 2007), p. 5; Federal Prosecutor v. Berehene Kehassaye et al., FHC (Judgment of 19 April 2007) File No. 45671/98, p. 7; Federal Prosecutor v. Kifle Tigeneh et al., FHC (Ruling of 16 April 2007) File No. 44562, p. 23.

10 See Gure Uchala et al. (Sentencing Judgment of 30 March 2005), pp. 1-3.

11 Aliyu Yesufe et al. (Sentencing Judgment of 5 Septembre 2009), pp. 1-6; Tadesse Jewannie et al. (Sentencing Judgment of 2 September 2009), pp. 1-4; Tesfaye Neno et al. (Sentencing Judgment of 20 May 2009), pp. 1-3.

12 'Dem Yazele Dossie' (Special Prosecutor's Office, Final Report, 2010), p. 464.

13 Rigorous imprisonment is defined in section 3.2.1. below. 
TABLE $1 \quad$ Summary of sentences imposed

\begin{tabular}{lrrrrc}
\hline Trials & \multicolumn{5}{c}{ Sentences imposed } \\
\cline { 2 - 6 } & Death & Life & $\mathbf{1 5}^{-\mathbf{2 5}}$ years & $\leq \mathbf{1 5}$ years & Minimum Sentence \\
\hline Dergue & $5^{2}$ & 182 & 921 & 2028 & 2 years \\
Anuak-Nuwer & - & - & - & 3 & 13 years \\
Oromo-Gumuz & 7 & 8 & 95 & 66 & 5 years \\
& & & & &
\end{tabular}

life in prison, and 95 individuals to rigorous imprisonment from 15 to 25 years. The Anuak-Nuwer trials punished génocidaires with the maximum of 14 years of rigorous imprisonment (see Table 1).

\section{Applicable Penalties for Core Crimes under Ethiopian Law}

Ethiopian criminal law (both the 1957 Penal Code and the 2005 Criminal Code) divides penalties into two categories: principal and secondary. The former is further divided into three: 1. compulsory labour; 2. pecuniary penalties; and 3. penalties entailing loss of liberty. The latter includes temporary or permanent deprivation of rights and dismissal from the defense forces. ${ }^{14}$ Secondary penalties may be imposed in addition to the principal penalties when deemed beneficial to the reform of the criminal and society at large. ${ }^{15}$ Unlike their international counterparts, Ethiopians found guilty of crimes were often deprived of certain rights in addition to the principal core penalties. This included barring an ex-police officer from resuming professional work as a detective for a certain number of years after serving a prison term for unlawful detention and torture (see Table 2$) \cdot{ }^{16}$

\subsection{Pecuniary Penalties}

In relation to pecuniary penalties (fines and confiscation of property), ${ }^{17}$ a significant point of departure between Ethiopian law and the laws of the ICC

14 The Criminal Code of the Federal Democratic Republic of Ethiopia, Proclamation No. 414/2004 entered into force 9 May 2005 [FDRE Criminal Code], Articles 121-128.

15 Ibid., Article 123.

16 See for instance, SPO v. Gebremedehene Berga et al., FHC (Sentencing Judgment of 11 April 2001) File no. 646/89, p. 7 .

17 See FDRE Criminal Code, Book II, Chapter II. 
TABLE 2 Penalties applicable to core crimes: Ethiopian law vis-à-vis the Statutes of the ICC and UNICTS

\begin{tabular}{|c|c|c|c|c|}
\hline Penalty & Ethiopian law & ICC & ICTR & ICTY \\
\hline Death & $\sqrt{ }$ & $\mathrm{X}$ & $\mathrm{X}$ & $\mathrm{X}$ \\
\hline Life & $\sqrt{ }$ & $\sqrt{18}$ & $\sqrt{ }$ & $\sqrt{ }$ \\
\hline Prison terms & $5^{-25}$ years & 30 years maximum & no limit & no limit \\
\hline Fine & $\begin{array}{l}\text { If committed with } \\
\text { a motive of gain }\end{array}$ & $\sqrt{ }$ & $\mathrm{X}$ & $\mathrm{X}$ \\
\hline $\begin{array}{l}\text { Compulsory } \\
\text { labour }\end{array}$ & $\begin{array}{l}\text { If the convict fails } \\
\text { to pay fines }\end{array}$ & $\mathrm{X}$ & $\mathrm{X}$ & $\mathrm{X}$ \\
\hline $\begin{array}{l}\text { Confiscation and } \\
\text { return of property }\end{array}$ & $\mathrm{X}$ & $\sqrt{ }$ & $\sqrt{ }$ & $\sqrt{ }$ \\
\hline $\begin{array}{l}\text { Secondary } \\
\text { penalties }\end{array}$ & $\sqrt{ }$ & $\mathrm{X}$ & $\mathrm{X}$ & $\mathrm{X}$ \\
\hline
\end{tabular}

X: Not applicable $\sqrt{ }$ : Applicable

and the UNICTS concerns the confiscation and return of property acquired, directly or indirectly, through the commission of a crime. This penalty is provided both in the Statute of the ICC ${ }^{19}$ and in those of the UNICTs, ${ }^{20}$ although in the case of the latter it has not been applied, even when circumstances demanded it. ${ }^{21}$ Ethiopian law does not allow the applicability of this penalty for core crimes. As a result, and apparently owing to the application of the principle nulla poena sine lege, Ethiopian courts have refrained from entertaining the issue of confiscation and return of property despite the existence of proof that perpetrators had indeed acquired the property of their victims. ${ }^{22}$

In contrast to the Statutes of the ICTR and ICTY, which exclude fines as a form of punishment, ${ }^{23}$ Ethiopian law allows for the imposition of fines,

18 Exceptionally, when justified by 'the extreme gravity of the crime and the individual circumstances of the convicted person'. See Icc Statute, Article 77(1)(b).

19 ICC Statute, Article 77(2)(b).

20 ICTR Statute, Article 23(3); ICTY Statute, Article 24(3).

21 See for details, Guénaël Mettraux, International Crimes and the Ad Hoc Tribunals (Oxford University Press, Oxford, 2005) p. $35^{8}$.

22 See in this regard, Worku Fekadu and Shume Ararsso v. Prosecutor for Benishangul-Gumuz Regional State, FSC Cassation Bench (Decision of 25 January 2013), File No. 75387, pp. 2-3.

23 See Prosecutor v. Kambanda, ICTR (Judgment and Sentence of 4 September 1998), Case No. ICTR 97-23-S, para. 10. 
in addition to imprisonment, in a manner that is more or less similar to the ICC Statute. ${ }^{24}$ It is the commission of a crime with a motive of gain, irrespective of whether the gain is an essential element of the crime, that exceptionally justifies the imposition of fines under Ethiopian law. ${ }^{25}$ Both the Ethiopian Criminal Code and the ICc Statute provide for mandatory payment of fines. In case of default, Ethiopian courts may as a last resort pronounce that the convicted person performs compulsory labour for the State for a maximum of two years ${ }^{26}$ while the ICC can extend prison terms by up to five years. $^{27}$

Nonetheless, none of the Ethiopian core crimes trials have imposed fines, even when the existence of a motive of gain was pointed out to be the reason behind the commission of genocide. For instance, in the Oromo-Gumuz trials, the motive behind the genocidal act of the Gumuz against the Oromo farmers living along the borders of the two regional states was to acquire disputed land occupied by the farmers. ${ }^{28}$ Not only did the court fail to consider imposing fines in these cases, but it also did not apply the existence of the motive of gain as an aggravating factor, which would have been possible under Article 86 of the Criminal Code. This Ethiopian practice is in stark contrast with the practice of the ICC, which has considered the imposition of fines in its sentencing decisions in Katanga, ${ }^{29}$ and in Lubanga, ${ }^{30}$ although it actually imposed no fine in both cases due to, respectively, the defendant's impecuniousness and absence of evidence of any assets.

24 ICC Statute, Article 77(2)(a); ICC Rules of Procedure and Evidence, Rule 146. See also Rebecca Young, 'Fines and Forfeiture in International Criminal Justice', in Róisín Mulgrew and Denis Abels (eds.), Research Handbook on the International Penal System (Cambridge University Press, Cambridge, 2016) pp. 109-111.

25 See FDre Criminal Code, Article 92 (2).

26 This happens when the defendant, who cannot produce sureties and securities, has no property that can be seized and sold or is unwilling to perform some work for the state. See FDRE Criminal Code, Articles 93-96.

27 ICC Rules of Procedures and Evidence, Rule 46(5).

28 See Tadesse Jewannie et al., supra note 11, pp. 6-7; Tesfaye Neno et al. (Judgment of 30 April 2009), p. 4.

29 Prosecutor v. Germain Katanga, Trial Chamber II (Sentencing Judgment of 23 May 2014), CC-01/04-01/07-3484, para. 169 .

30 Prosecutor v. Thomas Lubanga Dyilo, Trial Chamber I (sentencing Judgment of 10 July 2012) ICC01/04-01/06-2901, para. 106. 


\subsection{Penalties Entailing Loss of Liberty}

As for penalties that entail temporary or permanent loss of liberty, which are the primary forms of punishment applicable to core crimes, Ethiopian law authorises the imposition of prison terms which range from 10 days to life in prison. ${ }^{31}$ It also prescribes a penalty that has been abolished from the international arena, the death penalty. ${ }^{32}$ Genocide is punishable with a minimum of 5 years of rigorous imprisonment. ${ }^{33}$ This minimum penalty is prescribed for 7 of the 13 war crimes proscribed in Ethiopian law. ${ }^{34}$ The maximum sentence a court can impose for both categories of core crime is the death sentence. ${ }^{35}$ Inchoate crimes such as conspiracy and incitement to commit genocide or war crimes are punishable with rigorous imprisonment not exceeding five years. ${ }^{36}$ The following section provides a separate discussion of penalties entailing loss of liberty with a particular focus on their applicability to core crimes.

\subsubsection{Rigorous Imprisonment for 5 to 25 Years}

Rigorous imprisonment applies to grave crimes committed by criminals who are particularly dangerous to society. ${ }^{37}$ This type of imprisonment ranges from a period of one year to life, and is accompanied by more severe conditions of imprisonment, as compared to simple imprisonment. ${ }^{38}$ Although there is no guidance in the law as to what sort of conditions are to be considered severe enough for this purpose, the conditions of imprisonment must always respect the human dignity of the prisoner and comply with international

$31 \quad$ FDRE Criminal Code, Article 108.

32 William Schabas, 'International Law and the Abolition of Death Penalty', 55(3) Washington and Lee Law Review (1998) 798-799.

33 The Penal Code of the Empire of Ethiopia of 1957, Proclamation No. 158/1957, Extraordinary Issue No. 1, of 1957 of the Negarit Gazeta, 23 July 1957, entered into force 5 May 1958 [1957 Penal Code], Article 281; FD RE Criminal Code, Article 269.

34 These are: war crimes against a civilian population, war crimes against wounded sick or shipwrecked persons or medical services, war crimes against prisoners and interned persons, pillage, piracy and looting, dereliction of duty towards the enemy, use of illegal means of combat, and franc-tireurs. See 1957 Penal Code, Articles 270, 271, 273, 275, 277, and 278 .

35 Ibid.

$36 \quad$ Ibid., Art. 274.

37 See 1957 Penal Code of Ethiopia, Article 107; FD RE Criminal Code, Article 108. The Amharic

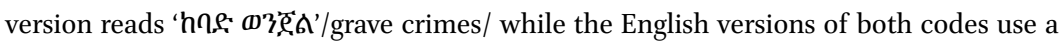
different expression, namely 'offences of a very grave nature'.

38 See ibid., Article 106. 
human rights law - a Constitutional promise that practice often fails to uphold. ${ }^{39}$

The 5 years of rigorous imprisonment prescribed as a minimum penalty for genocide and the above-mentioned categories of war crimes has not always been seen as proportionate to the gravity of these crimes. For instance, an attempt was made in a Draft Criminal Code completed in 1989 to increase it to 10 years of rigorous imprisonment. ${ }^{40}$ This has never materialized. Besides, several other offences which were punishable with a minimum penalty of 5 years under the Penal Code now carry a more severe minimum penalty, that is, 10 years of rigorous imprisonment. ${ }^{41}$

The Criminal Code's failure to apply the same minimum penalty for core crimes has resulted in the application of an absurd penalty scheme. To elucidate this, one needs to look at the crime of attack on the political or territorial integrity of the State, a crime punishable with a minimum of 10 years of imprisonment. ${ }^{42}$ This crime, as interpreted in Federal Prosecutor v. Waltajji Begalo et al, comprises acts constituting a forcible transfer of people from one regional state to the other. ${ }^{43}$ The exact same acts are regarded as underlying offences of genocide or war crimes. ${ }^{44}$ Consequently, these acts are punishable more leniently (with 5 years of rigorous imprisonment) when perpetrated with an ulterior intent, that is, when committed with intent to destroy a protected group in case of genocide or with a nexus to an armed conflict in the case of war crimes.

A similar contradiction exists when the offence of aggravated homicide is involved, which carries a minimum sentence of rigorous imprisonment for life. ${ }^{45}$ Paradoxically, when an aggravated homicide is committed as an underlying offence to genocide or war crimes the penalty could be as lenient as 5 years of

39 See the FDRE Constitution, Articles 13(2) and 21(2). Nonetheless, prison observation reports indicate the existence in Ethiopia of treatment in violation of international human rights law. See for instance, Un Committee Against Torture (CAT), Concluding observations of the Committee against Torture: Ethiopia, 20 January 2011, СAT/C/ETH/CO/1, paras. 10, 26, 29, available at: http://www.refworld.org/docid/4d6cca412.html, accessed 20 July 2018.

Draft Criminal Code of Peoples Democratic Republic of Ethiopia, September 1989, Article 281.

See FDRE Criminal Code, Articles 240-241, 249, 407-408, 411, 413-415, 512, 573, 596, 690.

42 Ibid., Article 241.

43 See Federal Prosecutor v. Waltajji Begalo et al., FHC (Judgment of 26 February 2015) File No. 136639, p. 22.

44 See FDre Criminal Code, Articles 269(1) and 270(1).

45 Ibid., Article 439. 
rigorous imprisonment. As was also seen in Aman Gobena et al. and Abdulekadir Mohammed Burka, which dealt with aggravated homicide as a purely domestic crime, the absurdity of the sentencing scheme is profound. ${ }^{46}$ In both cases, the courts have taken the life sentence as the minimum penalty applicable, which they then aggravated into the death sentence. ${ }^{47}$ In contrast, in several cases involving genocide and war crimes through the commission of aggravated homicide, the lower reference point for punishment was 5 years of rigorous imprisonment, which took several levels and grounds of aggravation for a convict to be sentenced to life imprisonment, let alone to death. ${ }^{48}$

It should be pointed out here that the 5 years of imprisonment that the core crimes carry is not the absolute minimum. Courts may, pursuant to Article 180 of the Criminal Code, freely mitigate it to a prison term of as low as 1 year of rigorous imprisonment. ${ }^{49}$ Nonetheless, the maximum prison term of 25 years that the core crimes carry is the absolute maximum, which judges are not allowed to exceed no matter what the case may be. ${ }^{50}$ As such, as far as a fixed prison term is concerned, core crimes are punishable in Ethiopia with a lower penalty than what the ICC Statute permits as the maximum, namely 30 years of imprisonment. ${ }^{51}$ Similarly, the ICTR and the ICTY (where prison terms for specified years could, in principle, be unlimited) have punished perpetrators of core crimes, in several cases, with a fixed prison term that is way more than the maximum allowed in Ethiopia. In Nyiramasuhuko et al. and Krstić, the tribunals have imposed their longest prison terms to date, that is, respectively, 47 and 46 years of imprisonment. ${ }^{52}$

$46 S P O$ v. Aman Gobena et al., Oromia Supreme Court (Sentencing Judgment of 23 April 2002), File No. 8/92, pp. 7-9; SPO v. Abdulekadir Mohammed Burka, FHC (Sentencing Judgment of 13 July 2004) File No. 17011, p. 4.

$47 \quad$ Ibid.

48 See for instance, SPO v. Negash Woldemichael et al., FHC (Sentencing Judgment of 17 November 2006), File No. 03114, pp. 4-6; sPO v. Seleshi Mekuria et al., FHC (Sentencing Judgment of 8 November 2000), File No. 959/89, pp. 1-3.

49 See infra section 4.2.1.

$50 \quad$ FDRE Criminal Code, Article 108.

$5^{1} \quad$ ICC Statute, Article 77.

52 See Prosecutor v. Pauline Nyiramasuhuko et al. (Appeal Judgement of 14 December 2015), ICT R-98-42-A, para. 3523; Prosecutor v. Krstić (Judgment of 2 August 2001) IT-98-33, para. 726. The Appeals Chamber had in fact reduced Krstic's punishment to 35 years of imprisonment. See Prosecutor v. Krstić (Appeal Judgment of 19 April 2004) Case No. IT-98-33-A, paras. $5^{-38}$. 


\subsubsection{Life Imprisonment}

A life sentence, the ultimate penalty in the international system, ${ }^{53}$ has always been one of the applicable penalties in Ethiopia since the enactment of the country's first penal code in 1930. ${ }^{54}$ Currently, about 45 offences in the 2005 Criminal Code are punishable by life sentence. This includes genocide and the 7 war crimes mentioned above.

A life sentence in Ethiopia has a unique position in the sense that the law avoids any possible confusion between life sentence and fixed prison terms on the one hand and between a life sentence and the death penalty on the other. By limiting the maximum prison term to twenty-five years even in cases of concurrent crimes, the law avoids the addition of sentences to impose a prison term that may be tantamount to life in prison or even go beyond, a problem witnessed in the case of UN ICTs, as discussed below.

Life imprisonment under Ethiopian law does not amount, in reality, to what some referred to as 'putting an individual in a waiting room until [her or his] death'. ${ }^{55}$ Similar to the Rome Statute of the ICc that provides for life imprisonment with the possibility of parole, ${ }^{56}$ Ethiopian law is compatible with the jurisprudence of regional human rights courts which considers irreducible life sentences as inhuman and degrading treatment. ${ }^{57}$ According to the Criminal Code, the adoption of life imprisonment without depriving convicts of any hope of release indicates the major place it 'has allocated for the rehabilitation of offenders' 58

Under Article 202 of the Criminal Code, a lifer is eligible for conditional release upon serving 20 years of the sentence. This eligibility criterion is set at 25 years by the Rome Statute. ${ }^{59}$ The law at the ICTR and the ICTY has undergone

53 See ICC Statute, Article 77(1)(B); Rules of Procedure and Evidence, ICTY and ICTR, Rule 101(A). To date, the ICTY has imposed 6 life sentences. See http://www.icty.org/en/cases/ judgement-list, accessed 30 August 2018.

54 Penal Code of Ethiopia, entered into force September 1930, Articles 161-190.

55 Gauthier de Beco, 'Life Sentences and Human Dignity', 9(3) The International Journal of Human Rights (2005) 414.

56 ICC Statute, Article 110(3).

57 See Kafkaris v. Cyprus, ECHR (Judgment of 12 February 2008) Application no. 21906/04, paras. 97-108; Vinter and Others v. the United Kingdom, ЕC н (Grand Chamber Judgment of 9 July 2013) Applications nos. 66069/og, 130/10 and 3896/10, paras. 119-122.

58 FDRE Criminal Code, Preface, p. IV.

59 ICC Statute, Article 110(3). 
an evolution. Up until the Galic early release decision in 2015, it was the law of the State in which the convicted person was imprisoned that determined the lifer's eligibility for early release, a reality that raised a concern regarding the equal treatment of similarly-situated convicts. Since Galić, a sentence of life imprisonment has been considered as equivalent to a hypothetical sentence of at least 45 years, and a lifer may be released upon having served two-thirds of a life sentence, which is 'more than 30 years'. ${ }^{60}$ For the sake of consistency, this criterion remained intact despite the jurisprudential change introduced by the Nyiramasahuko appeal judgment, which, on 14 December 2015, reduced a life sentence to 47 years. ${ }^{61}$

Upon granting early release, an Ethiopian court may require the prisoner to undergo a period of probation of five to seven years. ${ }^{62}$ However, a persistent recidivist, ${ }^{63}$ that is a person who repeats the commission of a crime more than once, is not eligible for early release. ${ }^{64}$ This exception is, perhaps, not relevant to core crimes, in relation to which recidivism appears to be not common, as highlighted in the jurisprudence of the UNICTs as well as in the sentencing decision of the ICC in AlMahdi. ${ }^{65}$

\subsubsection{The Death Penalty}

The death penalty has a basis in the Ethiopian Constitution and can be carried out as long as the President ${ }^{66}$ approves it by denying amnesty or pardon. ${ }^{67}$ Nonetheless, executions are not as frequent as the number of death sentences imposed. As stated in a study conducted in 2013, only three reported executions

6 See Prosecutor v. Stanislav Galić (Reasons for the President's Decision to Deny the Early Release of Stanislav Galić and Decision on Prosecution Motion of 23 June 2015), MICT14-83-ES, public redacted version, paras. 35 and 36.

61 Prosecutor v. Stanislav Galić (Reasons for the President's Decision to Deny the Early Release of Stanislav Galić of 18 January 2017), MICT-14-83-ES, public redacted version, para. 21.

62 FDRE Criminal Code, Articles, 204, 205, 208.

63 Ibid., Article 202(2).

64 Ibid., Article 188.

65 See Prosecutor v. Ahmad Al Faqi Al Mahdi, Trial Chamber viII (Judgment and sentence of 27 September 2016) ICC-01-12-01/15, para. 96.

66 The President is the head of the State with nominal and ceremonial powers, unlike the Prime Minister who is the head of the government with actual powers including chief executive and the commander-in-chief of the armed forces. FDRE Criminal Code, Article $117(2)$. 
were carried out in Ethiopia since $1991 .^{68}$ There have since been no reported instances of execution.

One may, of course, read a political motive into the enforcement of death sentences in Ethiopia. The three executions carried out were against prisoners convicted of committing offences in which the victims were top-ranking military or government (Ethiopian or foreign) officials. ${ }^{69}$ However, it may not mean that the death penalty has been abolished for non-political crimes. The reason behind the rarity of the enforcement of death sentences is far from clear. The required relevant information is inaccessible; which may relate, according to Amnesty International, to a general lack of government transparency. ${ }^{70}$

Evidently, there is no indication that Ethiopia intends to abolish the death penalty in practice. It is among the countries that have consistently voted against UN General Assembly resolutions on a moratorium on the use of the death penalty. ${ }^{71}$ Furthermore, in a more direct encounter with core crimes, that is, at the Rome Diplomatic Conference held from 15 June to 17 July 1998 to draft the Rome Statute of the ICC, Ethiopia expressed its preference to keep the death penalty. ${ }^{72}$ It also endorsed the view that the 'death penalty is not a human rights issue. ${ }^{73}$

Once approved by the President, the death sentence should be enforced forthwith, except when the law requires the suspension of the execution owing to full or partial irresponsibility, serious illness, or the pregnancy of the person awaiting execution. ${ }^{74}$ Nevertheless, there is no time frame in which the President shall exercise her or his prerogative to approve the enforcement of the

68 A. Kesito, 'Death Penalty in Ethiopia' (September 2013, Adama) (unpublished), pp. 20-25.

69 It was the assassination of Hayelom Araya, a Major General, and Kinfe Gebre-Medehin, the country's head of intelligence and security services that justified, respectively, the first and second executions. In the third case, three individuals were executed for killing two members of the Ethiopian security forces that intervened in a shootout to avert the assassination attempt carried out in 1995 against Hosni Mubarak, the then Egyptian President, in Addis Ababa. See ibid.

Amnesty International, 'Death Sentences and Executions in 2013', 26 March 2014, 43, available at http://www.amnestyusa.org/sites/default/files/act500012014en.pdf, accessed: 15 August 2018.

72 See William Schabas, Death Penalty in International Law ( $3^{\text {rd }}$ ed., Cambridge University Press, Cambridge, 2002) 257-258.

73 Ibid., 258.

74 FDRE Criminal Code, Article 119. 
death sentence. As the President's silence does not amount to a disapproval of the death sentence, there is nothing in the law that guarantees the release or commutation of a sentence of a prisoner awaiting execution in cases when the President does not consent to execution.

A person condemned to death is required to await execution in prison under the same conditions as a prisoner serving rigorous imprisonment. ${ }^{75} \mathrm{Ar}-$ ticle 224 of the Criminal Code provides that the prisoner may remain on death row for as long as 30 years - the expiry of which renders the death sentence unenforceable. This is no doubt a very long period to endure, to borrow the ECtHR's expression in Soering, 'the anguish and mounting tension of living in the ever-present shadow of death. ${ }^{76}$ Given that the conditions of confinement in Ethiopia exhibit the presence of the death row phenomenon, ${ }^{77}$ the law and practice may raise concerns regarding the existence of inhuman and degrading treatment of prisoners awaiting executions.

Interestingly, the death penalty in Ethiopia cannot be imposed: $(i)$ in relation to attempted crimes, (ii) on criminals below 18 years of age, and (iii) if there is a mitigating factor. ${ }^{78}$ In respect of the third element, the FHC underscored in Mengistu et al. that 'the availability of multiple aggravating factors is not per se sufficient to impose the death penalty unless the court ascertains the absence of a mitigating factor. ${ }^{79}$ Nonetheless, this requirement of the law is seldom upheld in practice. ${ }^{80}$

\section{Sentencing Rationales}

The absence of clear guidance in relation to sentencing rationales in the founding documents of the UNICTS and the ICC, which has been considered one of the challenges in international sentencing practice, is, to a certain degree, not a problem in the Ethiopian legal system. Article 1 of the Criminal Code lays down the goals of the criminal law and the rationales of punishment. ${ }^{81}$

\footnotetext{
75 Ibid., Article 118.

76 Soering v. United Kingdom, ECtHR (Judgment of 7 July 1989), Application No. 14038/88, para. 106.

77 UN Committee Against Torture (CAT), supra note 39, para. 24.

78 FDRE Criminal Code, Article 119.

79 See SPO v. Mengistu Hailemariam et al., FHC (Sentencing Judgment of 11 January 2007) File No. 401, pp 8-9.

8o See below section 5.2.2.

81 This was also the case with the Penal Code of 1957.
} 
Nonetheless, as all available rationales of sentencing are meant to apply to all types of crimes, it is therefore up to a particular court to choose and apply the rationale it deems appropriate to punish core crimes. In practice, however, the Ethiopian courts do not do more than recite in general terms the rationales available in the law, as shown below. This is also the case in international sentencing practice where courts often do not detail the impact a particular sentencing rationale has on the calculation of the actual sentence. ${ }^{82}$

The 1957 Penal Code was both utilitarian and retributivist in its sentencing rationales. It aimed at 'providing for...the reform of offenders and measures to prevent the commission of further crimes', and was, therefore, utilitarian in purpose. ${ }^{83}$ In referring to retribution, the code stated its aim as 'providing for the punishment of offenders. ${ }^{84}$ The Criminal Code however appears to have implicitly excluded the latter by confining the aims of punishment to deterrence (specific and general), rehabilitation and incapacitation. ${ }^{85}$

Ethiopian courts appear to have rejected retribution even before its official exclusion by the Criminal Code. It was not invoked as a rationale even in the Dergue and the Anuak-Nuwer cases where sentences were pronounced on the basis of the Penal Code. This makes Ethiopian practice stand in marked contrast to the way the UNICTS and the ICC have invoked sentencing rationales, in which retribution has been regarded as the principal purpose of punishment. ${ }^{86}$

What makes the sentencing approach followed by Ethiopian courts different, if not problematic, is not just the exclusion of retribution, but that it was excluded because it might have been seen as equivalent to vengeance. Some courts appeared to have based their sentencing decisions on a retributive rationale using expressions such as 'an offender should be punished because he broke the law' ${ }^{87}$ Nonetheless, they often fail to drive the argument home for an

82 See Silvia D'Ascoli, Sentencing in International Criminal Law: The UN ad hoc Tribunals and Future Perspectives for the ICc (Hart Publishing, Oxford, 2011) p. 207.

83 See Penal Code of 1957, Amharic version, Article 1.

84 Ibid. See however, Philip Graven, An Introduction to Ethiopian Penal Law: Arts. 1-84 Penal Code (Faculty of Law, Haile Selassie I University, in association with Oxford University Press, Addis Ababa-Nairobi, 1965), pp. 7-8.

85 FDRE Criminal Code, Article 1.

86 See Prosecutor v. Aleksovski (Appeal) IT-95-14/1-A (24 March 2000) para. 185; Prosecutor v. Kordic and Cerkez (Appeal) IT-95-14/2-A (17 December 2004), para. 1075; Prosecutor v. Rutaganira (Judgment) ICTR-95-3-T (14 March 2005), paras. 108-109; Prosecutor v. Germain Katanga (Sentencing Judgment of 23 May 2014), para. 38.

$87 S P O$ v. Sisay Balachew et al., Amhara Supreme Court (Sentencing judgment of 25 April 2002), File No. 9/92, p. 148; SPO v. Yekuno Amelak et al., Tigray Supreme Court (Sentencing judgment of 3 March 2003) File No. 4/92, p. 1866. 
apparent fear that such reasoning could easily be associated with or mistaken for an expression of vengeance. ${ }^{88}$

Given that both the defendants and commentators have widely accused the Dergue trials of exercising victor's justice and vengeance, it is understandable that the courts might have wanted to send a positive message as to the impartiality of the proceedings. Arguably, that is partly why in Mengistu et al., the FHC rejected the death penalty by stating that in the given circumstances imposing the death penalty serves no purpose other than vengeance'. ${ }^{89}$ Nonetheless, while disavowing vengeance as the purpose of punishment is one thing, emphasizing the fact that retribution is not an expression of vengeance is another. That is apparently what the UNICTs and the ICC have been doing by persistently reiterating a disclaimer that retribution as a purpose of punishment is not an expression of vengeance, but an expression of the international community's condemnation of core crimes. ${ }^{90}$

Concerning deterrence (specific or general), Ethiopian courts have recited the Criminal Code's statement that 'punishment can deter wrongdoers from committing other crimes; it can also serve as a warning to prospective wrongdoers.' ${ }^{91}$ Several courts have however attached a significant amount of emphasis to the importance of specific deterrence. ${ }^{92}$ The UNICTs have, by contrast, treated specific deterrence as a less important sentencing rationale, because the commission of core crimes is seen as dependent upon the existence of a political context that goes well beyond the will of any particular individual. ${ }^{93}$ Despite the courts' insistence on specific deterrence, this context was also true in Ethiopia - core crimes could not have been committed without the participation of a large number of people in orchestrating and implementing state and organizational plan or policy. ${ }^{94}$ Such a reality renders

\footnotetext{
$88 \quad$ Ibid.

89 See Mengistu Hailemariam et al., supra note 79, p. 9.

9o Prosecutor v. Momir Nikolić (Sentencing Judgment of 12 December 2003), ICTY-IT02-6o/1/s, paras. 86-87; Al Mahdi, supra note 61, para. 67 .

91 Ibid., Preface, p. IV.

92 See SPO v. Aregaw Hailemariam et al. (Sentencing judgment of 14 July 2005) SNNPR Supreme Court, File No. 3647, p. 51; SPO v. Yekuno Amelak et al. (sentencing judgment of 3 March 2003), Tigray Supreme Court, File No. 4/92, p. 1866.

93 See Prosecutor v. Ntakirutimana et al. (Judgment of 21 February 2003), ICT R-96-10, para. 882. See also W. Schabas, The UN International Criminal Tribunals: The Former Yugoslavia, Rwanda and Sierra Leone (Oxford University Press, Oxford, 2006) 557.

94 See for instance $S P O$ v. Mengistu Hailemariam et al., FHC (Judgment of 12 December 2006), File No. 401, p. 116.
} 
recidivism less likely. This should have been reflected in the sentencing by paying more emphasis to general deterrence and less to specific deterrence.

As for rehabilitation, to which the law claims to be paying greater attention than any of its other aims, ${ }^{95}$ case-law has often mentioned it without explanation and always together with other purposes of punishment such as general and specific deterrence. As such, the role it played in determining and justifying specific sentences is not very clear. Due to this lack of transparency in sentencing, it is difficult to compare and contrast Ethiopian practice with its international counterparts, where rehabilitation is regarded as playing a marginal role, given the gravity of core crimes. ${ }^{96}$

Lastly, it is noteworthy that some courts have justified punishment using rationales that are not listed in the statutory law, namely 'healing victims' wounds', ${ }^{97}$ 'preparing perpetrators for reconciliation', ${ }^{98}$ and 'ensuring respect for the human rights of life and liberty' ${ }^{99}$ Likewise, the UNICTs have created justifications such as 'reconciliation' which do not belong to the traditional sentencing rationales. ${ }^{100}$ In both systems, however, the new rationales do not appear to have served more than a nominal purpose. As for the Ethiopian courts, however, this practice of creating new rationales is unwarranted, because the law does not give judges the discretion to do so.

The determination of the appropriate penalty under Ethiopian law depends on the analysis of: 1 . the gravity of the crime and the circumstances of its commission, and 2. the degree of individual guilt. ${ }^{101}$ As shall be seen, courts need to

\footnotetext{
95 See infra.

96 See Prosecutor v. Zejnil Delalić et al., ICTY (Appeal Judgment of 20 February 2001), IT-96-21-A, para. 8o6.

97 See SPO v. Gesgese Gebremeskel et al., FHC (Sentencing Judgment of 23 December 2001) File No. 03099/1989, p. 4.

98 Mengistu Hailemariam et al., supra note 79, p. 16.

99 SPO v. Eshetu Alemu, FHC (Sentencing Judgment of 8 May 200o), File No. 921/89, p. 3.

100 See Prosecutor v. Kamuhanda, ICTR (Judgment of 22 January 2004), ICTR-95-54A-T, para. 754; ICTY Prosecutor v. Momir Nikolić, ICTY (Judgment of 2 December 2003), IT-02-6o/1-s, para. 93.

101 See FDre Criminal Code, Article 88 (2). See also Bihonegn Demessie v. Tigray Regional State Prosecutor, FSC Cassation Bench (Decision of 24 July 2013) File no. 88542, p. 3.
} 
distinguish between the two factors and treat them separately to avoid doublecounting, i.e. using the same aggravating or mitigating factor twice. ${ }^{102}$

\subsection{Gravity of the Crime and the Circumstances of its Commission: The Initial Penalty}

As discussed above in section 2, Ethiopian law prescribed the minimum and maximum penalties for each of the acts it proscribes based on whether they are minor, not serious, grave, or extremely grave. As such, it is within the power of the legislator, not the courts, to make a general determination as to whether a particular crime is graver than other crimes. In other words, there is no judicial comparison in Ethiopia as to whether, for instance, genocide is graver than war crimes, or even whether a core crime is more severe than domestic crimes.

This does not mean that courts do not determine the gravity of the specific offence under consideration for sentencing. In fact, a court has to determine the gravity of any particular crime for which the defendant is found guilty. Doing so is a prerequisite for the specification of the initial penalty, i.e. the specific penalty the court has to indicate by choosing from the minimum and maximum sentences set by the law. This has to be specified at the beginning of the sentencing stage as it serves as a preliminary or 'hypothetical'103 penalty upon which the court bases itself to calculate mitigating or aggravating factors and pronounce the final sentence. The court's choice of the initial penalty usually depends on its assessment of the gravity of the crime committed that it has to establish from the circumstances of its commission. ${ }^{104}$

In reality, the circumstances of the commission of a crime could also constitute aggravating or mitigating factors, ${ }^{105}$ which are to be taken into consideration after the initial penalty has been determined. ${ }^{106}$ The many sentencing judgments analysed in this study indicate that, except, notably, in the war crimes case, ${ }^{107}$ Ethiopian courts have not specified in their sentencing

\footnotetext{
102 See FDre Criminal Code, Articles 82(2) and 84(2).

103 See Graven, supra note 84, p. 268.

104 See $S P O$ v. Legesse Asfaw et al., FHC (Sentencing Judgment of 4 April 2008), File No. 03116, pp. 12-13; see also Revised Sentencing Guideline, No. 2/2013, Articles 4(1), 4(4) and 19(5).

105 See Fesseha Tadesse Mewucha v. Federal Prosecutor, Fsc Cassation Bench (Decision of 4 October 2014), File no. 80815, pp. 6-8; Revised Sentencing Guideline, Article 19.

106 See FDRE Criminal Code, Articles 174-184; Revised Sentencing Guideline, Articles 19 and 26.

107 Legesse Asfaw et al., supra note 104, pp. 12-13.
} 
judgments the gravity they attached to a particular crime and the initial penalty they have chosen. As a result, it could be difficult to verify whether a specific sentencing judgment has involved double-counting by applying the same circumstances of commission to determine the gravity of the crime and to aggravate or mitigate the initial penalty. ${ }^{108}$

In contrast, as the international practice is more transparent, it avoids the occurrence of double-counting. In Lubanga, the ICC declined to consider the age of the children (Lubanga's victims) as an aggravating factor in order not to commit double aggravation. ${ }^{109}$ It is also an established practice of the UNICTs that double-counting if found to be significant, warrants reduction or addition of sentence by the Appeals Chamber. ${ }^{110}$ Most importantly, to avoid double-counting, the UNICTs' Trial Chambers shall 'consider and count all aspects and implications' of a sentencing factor it applied. ${ }^{111}$

A sentencing judgment's opacity has a different magnitude and effect in Ethiopia, as it became irremediable even on appeal. Firstly, as it is too difficult, if not impossible, to indicate specific grounds of appeal from an opaque judgment, most of the sentencing appeals carry a brief but general claim that a given sentence is unfair, i.e. too severe or too lenient. ${ }^{112}$ Secondly, this reality has, apparently, forced the FSC (the Court of Appeal) to unconventionally approach sentencing appeals by framing the issue as broadly as 'whether the sentence imposed appears unfair in the eyes of the law'.113 This has, ultimately, resulted in the appeals process being virtually a trial de novo, which

108 FDRE Criminal Code, Articles 82(2) and 84(2); see also, Federal Prosecutor v. Berihun Feka$d u$, FSC Cassation Bench (Decision of 10 June 2011) File no. 59356, p. 3; Graven, supra note 84, p. 268.

109 See Prosecutor v. Thomas Lubanga Dyilo, ICC-Trial Chamber I (Decision on Sentence Pursuant to Article 76 of the Statute, 10 July 2012), ICC-01/04-01/06, para. 78; Al Mahdi, supra note 61, paras. 87-88.

110 See Prosecutor v. Limaj et al., ICTY (Appeal Judgment of 27 September 2007), IT-03-66-A, paras. 143-144; Prosecutor v. Nicolić, ICTY (Appeal Judgment on Sentencing of 8 March 2006), IT-02-6o/I-A, para. 58.

111 See Prosecutor v. Dragomir Milosević, ICTY (Appeal Judgment of 12 November 2009) IT-98-29/1-A, para. 309 .

112 See for instance Abera Afewerke v. SPO, Federal Supreme Court (Appeal of 1 October 2002) File no. 7559, p. 7 .

113 See Geremew Qenno v. SPO, FSC (Judgment of 29 June 2001), File No. 6659, p. 7; Gizaw Tadesse et al. v. SPO, FSC (Judgment of 30 April 2002), File No. 6470, p. 12; Haregewoine v. SPO, FSC (Judgment of 29 October 2002), File No. 7369, p. 12; Maseresha Abebe v. SPO, FSC (2 July 2001), File No. 6688, p. 12; Teshome Kebede et al. v. SPO, FSC (Judgment of 
has no basis in Ethiopian law. ${ }^{114}$ This is also the case in the jurisprudence of the UNICTs. ${ }^{115}$

Ironically, the FSC has not done justice to the opacity problem. The appeal judgments are as opaque as those of the trial courts. In particular, the FSC does not examine or criticize the lower courts' failure to specify the initial penalty. Rather, it focuses on superficial and enigmatic assessments of sentencing factors, and, often, abruptly concludes that 'the sentence imposed does not appear to be too severe or too lenient' or that 'there is no ground to examine the trial court's sentencing judgment.'116

\subsection{The Degree of Individual Guilt: Mitigating and Aggravating the Initial Penalty}

In invoking the degree of individual guilt as a sentencing factor, Ethiopian courts may rely on, inter alia, the criminal's dangerous disposition, antecedents, motives, purpose, personal circumstances, and standard of education. ${ }^{117}$ These factors fall within the ambit of mitigating or aggravating circumstances. ${ }^{118}$ There are a complex set of rules that govern aggravation and mitigation and delineate the judge's discretion in sentencing.

Similar to its international counterparts, Ethiopian criminal law recognizes two types of aggravating and mitigating factors: statutory (listed in the Code) and judicial (judge-made). ${ }^{119}$ Ethiopian law further divides the statutory aggravating and mitigating factors into two: general and special. ${ }^{120}$ General mitigating or aggravating factors imply ordinary mitigation or aggravation, that is, mitigation or aggravation within, respectively, the minimum and maximum bounds of the penalty specific to the crime under consideration. ${ }^{121}$ Special

26 March 2002), File no. 6486, p. 8; Ziyad Alemu v. SPO, FSC (Judgment of 13 March 2002) File No. $735^{8}$, p. 4.

114 See Criminal Procedure Code of Ethiopia, Proclamation No. 185 of 1961, entered into force 2 February 1962, Article 194.

115 See Prosecutor v. Dragan Nikolić (Appeal Sentencing Judgment of 4 February 2005), IT-94-02-1, para. 8 .

116 See for instance, Feyissa Seboka v. SPO, FSC (Judgment of 1 June 2001), File No. 6509, p. 11; SPO v. Mergia Bededa, FSC (Judgment of 4 December 2006), File No. 21345, pp. 32, 44-46; Tolossa Waqoyya v. SPO, FSC (Judgment of 30 January 2003) File No. 7472, p. 10.

117 See FDRE Criminal Code, Article 88(2).

118 See Fesseha Tadesse Mewucha, supra note 105, pp. 8-11.

119 FDRE Criminal Code, Articles 84-85.

120 Ibid., Articles 82-85.

121 Ibid., Articles 179 and 183. 
mitigating and aggravating factors have a special effect - the so-called free mitigation or free aggravation. This special effect implies the power to go beyond the minimum or the maximum limits of the penalty for a specific crime and impose a sentence as low as the general minimum rigorous imprisonment (1 year) or as high as the general maximum rigorous imprisonment (25 years). ${ }^{122}$

Interestingly, there is no difference in weight among general aggravating or mitigating factors, be it statutory or judicial; each of them carries equal weight. Accordingly, it is not within the discretion of the court to attach less weight to one sentencing factor and more to another, unlike the case of the UNICTs and the ICc. ${ }^{123}$ The only difference of significance among the sentencing factors is the one that exists between the general and special ones.

\subsubsection{Special Mitigating Factors}

Generally, the special mitigating factors that justify free mitigation are family and affectionate relationships. ${ }^{124}$ Apparently, this provision is a continuation of the 1930 Penal Code's approach adopted to give effect to the traditionally strong family relationships in Ethiopia. ${ }^{125}$ Besides, factors that fall short of exculpating criminal responsibility may instead qualify as special mitigating factors upon express stipulation in the law to that effect. ${ }^{126}$

Of the three instances of core crime trials in Ethiopia, only the Dergue trials have applied free mitigation to punish génocidaires with sentences below the minimum limit of 5 years of rigorous imprisonment. This was particularly the case in Mekonnen Gelan et al., which imposed 2 and 4 years of rigorous imprisonment on, respectively, 14 and 9 defendants found guilty of genocide. ${ }^{127}$ To justify these sentences, the court invoked: ( $i$ ) the young age of the defendants at the time of the commission of the crime (defendants being high school students), (ii) lack of education (defendants being peasants), and (iii) the 'prevailing circumstances of the time', i.e. that there was a power struggle between the Dergue and the victims (opposition political groups), and the heinous crimes

122 Ibid., Articles 184-188.

123 See for instance, Prosecutor v. Germain Katanga, ICC-Trial Chamber II (Judgment of 23 May 2014), ICC-01/04/-01/o, paras. 143-144.

124 FDre Criminal Code, Article 83; Penal Code of 1957, Article 80.

125 Graven, supra note 84, pp. 248-249. See also, Penal Code of 1930, Article 236.

126 See Fdre Criminal Code, Articles 72, 74-77, 79, 81.

127 SPO v. Mekonnen Gelan et al., SNNPRSC (Sentencing Judgment of 4 June 2005) File No. 1338. pp. 312-314. 
were committed as a response to the multi-sided and intricate violence of the time. ${ }^{128}$

Nonetheless, the application of free mitigation in Mekonnen Gelan et al. is tricky. It was not only devoid of sufficient explanation but also relied on judicial mitigating factors to justify free mitigation. ${ }^{129}$ This is erroneous since judicial mitigating factors cannot be regarded as special mitigating factors, and, thus, do not apply in free mitigation. ${ }^{130}$

\subsubsection{General Mitigating Factors}

There are five general statutory mitigating factors in Ethiopian law: good character; acting with honourable and disinterested motive; justified fear (including obedience to superior orders); expression of sincere remorse; and provocation or mental distress. ${ }^{131}$ These factors are also available in the practice of the UNICTS and the ICC. ${ }^{132}$ In addition to applying the statutory mitigating factors, Ethiopian courts have exercised their broad discretion to invoke numerous grounds of mitigation.

In what signifies the most controversial example of the use of mitigating factors, the majority in Mengistu et al. pronounced a life sentence instead of the death penalty after identifying eight grounds of mitigation. ${ }^{133}$ These were: (i) the prevailing circumstances of the time of the commission, (ii) lack of education, (iii) old age, $(i v)$ age-related sickness, $(v)$ lengthy trial, $(v i)$ contribution to the defence of the country and international peacekeeping missions, (vii) reform during detention, and (viii) signs of remorse and reconciliation. ${ }^{134}$

On appeal, the FSC indefensibly rejected all of the FHC's mitigating factors and aggravated 18 life sentences to death sentences. ${ }^{135}$ Firstly, the reasons that the FSC put forward to reject the FHC's mitigating factors are too brief to be convincing, except for the eighth factor, in which it stated that the mere sign

\footnotetext{
128 Ibid., p. 313 .

129 See SPO v. Mergia Bededa, FSC (Judgment of 4 December 2006) File no. 21345, pp. $36-38$.

130 FDRE Criminal Code, Article 86.

131 Ibid., Article 82.

132 See Mettraux, supra note 21, pp. 351-352.

133 Mengistu Hailemariam et al., supra note 79, pp. 8-20.

134 Ibid., pp. 16-17.

135 See $S P O$ v. Mengistu Hailemariam et al., FSC (Appeal Judgment of 26 May 2008), File No. 30181, p. 95 .
} 
of remorse is not sufficient to mitigate a sentence. ${ }^{136}$ Furthermore, in rejecting the FHC's mitigating factors, the FSC runs into a contradiction not only with judgments of several other courts but also with its own decisions in comparable cases. ${ }^{137}$ For instance, unlike its conclusion in this case that 'being of old age and a victim of age associated-diseases is by no measurement a mitigating ground, ${ }^{138}$ the FSC has argued oppositely in Tiruneh Habteselassie v. SPO, where it mitigated a death sentence to life imprisonment on the sole basis of the appellant's sickness. ${ }^{139}$

Secondly, the FSC has unwarrantedly intervened with the trial court's broad discretion to create as many judicial mitigating factors as it may deem necessary. In this respect, it should be noted that Ethiopian trial judges enjoy a comparable degree of 'unfettered discretion' with that of international judges, in particular as far as creating (not applying) mitigating or aggravating factors are concerned. ${ }^{140}$ Nevertheless, in revising the FHC's sentencing judgment, the FSC did not show if the FHC had exercised its discretion to create judicial mitigating factors beyond what is permitted by law. As a result, the FSC's judgment amounts to unwarranted intervention with the discretion of the trial court. ${ }^{141}$ Such an exercise of appellate power is also not possible in international practice. ${ }^{142}$

It also appears from practice that Ethiopian courts have shown an implicit tendency to relegate mitigating factors, in particular when aggravating factors have an overwhelming presence. Arguably, that is what happened in the FSC's sentencing decision in Mengistu et al., where the court emphasized the gravity

136 Ibid., p. 90.

137 Regarding reform during detention, see SPO v. Tsegaye Mamo et al., FHC (Sentencing Judgment of 3 August 2003) File no. 631/89, p. 6. As for 'prevailing circumstances of the period', see SPO v. Denbi Disassa et al., Harari Supreme Court (Sentencing Judgment of 23 April 2004) File no. 3/95, p. 178; SPO v. Tadesse Tegegne et al., Harari Supreme Court (Sentencing Judgment of 23 July 2004), File no. 5/95, p. 83.

138 See Mengistu Hailemariam et al., supra note 135, p. 125.

139 See Tiruneh Habteselassie v. SPO, FSC (Appeal Judgment of 1 December 2006) File no. 21163, p. 21. For similar judgments by other courts, see SPO v. Aseffa Belay et al., Tigray Supreme Court (Judgment of 11 December 2003) File no. 5/90, p. 815.

140 Regarding the discretionary power of international judges, see Prosecutor v. Ruggiu, ICTR (Judgment and Sentence of 1 June 2000), ICTR-97-32-I, para. 34.

141 See the Criminal Procedure Code, Article 194.

142 See Prosecutor v. Kayishema et al., ICTR (Appeal Judgment of 4 December 2001), ICTR95-1-A, para. 337 . 
of the crimes and the extreme dangerousness of the convicts in order to impose the death penalty. Similarly, the FHC overlooked mitigating factors in $\mathrm{Ge}$ tachew Tek'eba (the first of the spo cases to pronounce the death penalty), ${ }^{143}$ Abdulkadir Mohammed Burka, ${ }^{144}$ Gesgese Gebremeskel et al., ${ }^{145}$ Tesfaye Woldeselassie et al., ${ }^{146}$ and Zenebe Ayele et al. ${ }^{147}$

The view that considers an aggravating factor capable of rendering a mitigating factor insignificant, if not inapplicable, finds support in international sentencing practice. For instance, the ICTY Appeals Chamber in Popović et al. stated in relation to the imposition of a life sentence, that, 'the existence of mitigating circumstances does not automatically result in a reduction of sentence or preclude the imposition of a sentence of life imprisonment where the gravity of the offence so requires.'.148

In reaching this conclusion, the Appeals Chamber in Popović relied on appeal judgments of the ICTR in Nizeyimana, ${ }^{149}$ Ntabakuze, ${ }^{150}$ and Niyitegeka, ${ }^{151}$ and thereby presented the point as an established practice of the UNICTs. Similarly, as noted in Blaškic et al. in connection to the defendant's position of power, an aggravating factor may either significantly increase the sentence or 'at least lead the Trial Chamber to give less weight to the mitigating circumstances'.152

Nonetheless, the law in Ethiopia is unequivocally different in the sense that neither a multiplicity nor the perceived weightiness of aggravating factors affects the application of mitigating factors. In fact, a single mitigating factor should result in an automatic reduction of a sentence, including the ultimate penalty. There should be a mandatory assessment of both aggravating and mitigating factors. Moreover, the courts should first aggravate the penalty on

143 See SPO v. Getachew Tek'eba, FHC (Sentencing Judgment of 9 November 1999), File no. $914 / 89$, p. 3 .

144 Abdulekadir Mohammed Burka, supra note 46, pp. 2-3.

145 Gesgese Gebremeskel et al., supra note 97, pp. 40-54.

146 SPO v. Tesfaye Woldeselassie et al., FHC (Sentencing Judgment of 4 August 2003) File no. 03101, pp. 26-32.

147 SPO v. Zenebe Ayele et al., FHC (Sentencing Judgment of 3 June 2003) File no. 641/89, pp. 109-112.

148 See Prosecutor v. Vujadin Popović et al., ICTY (Appeal Judgment of 30 January 2015) IT-05-88-A, para. 2053.

149 Prosecutor v. Nizeyimana, ICTR (Appeal Judgement of 29 September 2014), ICTR-0o-55CA, para. 445 .

$15^{0}$ Prosecutor v. Ntabakuze, ICTR (Appeal Judgement of 8 May 2012), ICTR-98-41A-A, paras. 267, 280 . 
the basis of any aggravating factors and then mitigate the sentence by applying mitigating factors. ${ }^{153}$ The crux of the matter is that there is a rule of separate treatment of mitigation and aggravation; and, as Philip Graven put it, the factors 'do not exclude each other'. ${ }^{154}$

\subsubsection{Special Aggravating Factors}

The special aggravating factors that engender free aggravation are in general concurrence of crimes and recidivism. ${ }^{155}$ The concurrence of crimes is the only special aggravating factor that has been used in Ethiopian trials of core crimes. It occurs when a person commits two or more successive crimes; when the same criminal act simultaneously contravenes several criminal provisions; or when the commission of a single crime harms the interests of more than one person. ${ }^{156}$ The vast majority of the Dergue trials and the Oromo-Gumuz trials used a multiplicity of convictions as special aggravating factors. Defendants were found to have committed a domestic crime (murder, grave bodily injury or rape) in addition to a core crime (genocide or war crimes). No single defendant was found guilty of both genocide and war crimes at the same time by the same court.

Pronouncing multiple sentences on a single criminal found guilty of multiple offences is not permissible under Ethiopian law. The court may determine separate sentences for each of the concurrent crimes knowing that at the end they would become a single sentence either by way of absorption or addition. ${ }^{157}$ The absorption rule applies to death sentences and life sentences. Once the death sentence is determined for one of the concurrent crimes, it may be taken as final for it absorbs any other penalty the court might impose for the other crimes. The same rule applies where the maximum penalty imposed for one of the concurrent crimes is a life sentence. ${ }^{158}$ The addition rule works with sentences of fixed prison terms. Accordingly, the court may add sentences imposed for each of the concurrent crimes and determine the

\footnotetext{
151 Prosecutorv. Niyitegeka, ICTR (Appeal Judgement of 9July 2004), ICTR-96-14-A, para. 267.

$15^{2}$ Prosecutor v. Blaškic, ICTY (Trial Judgment, 3 March 200o), IT-95-14-T, para. 789 (emphasis added).

153 FDRE Criminal Code, Article 189(1).

154 Graven, supra note 84, p. 269.

155 See Penal Code of 1957, Article 82; FDre Criminal Code, Article 85.

156 FDRE Criminal Code, Article 66.

157 Ibid., Articles 184-188.

$15^{8}$ Ibid., Article 184.
} 
final sentence, without exceeding the general maximum, 25 years of rigorous imprisonment. 159

Accordingly, Ethiopian law provides for a mandatory single sentence for multiple convictions. In that, it differs from the case of the UNICTs, where a trial chamber enjoys the discretion to impose a single penalty when the accused has been found guilty of multiple crimes that are linked together. ${ }^{160}$ Further, the existence of a single sentence rule in Ethiopia renders irrelevant issues that international practice deals with, namely consecutive or simultaneous enforcement of multiple sentences. The absorption and addition rules apply even to sentences passed on the same individual by different courts and at different times, as is the case with respect to defendants in the Dergue trials such as Melaku Teferra, Eshetu Alemu, Kebede Kiberet, Getachew Tekebe, and Legesse Asfaw. ${ }^{161}$

\subsubsection{General Aggravating Factors}

Similar to the number of general statutory mitigating factors, the Criminal Code identifies five general statutory aggravating factors, namely reprehensible motives, abuse of a position of power, the vulnerability of victims, vicious circumstances of the commission and participation in a criminal agreement. ${ }^{162}$ International practice has also taken similar factors of aggravation into account. ${ }^{163}$ Vicious circumstances of the commission and the abuse of a position of power have stood out in Ethiopian trials as justifying the most severe penalties.

In condemning convicts to death, the Dergue trials relied on the existence of vicious circumstances surrounding the commission of crimes such as violence against the dead, in which the dead were denied a proper burial, hauled across or dumped on the streets, thrown into mass graves or abysses, and fed to beasts. ${ }^{164}$ The Oromo-Gumuz trials have followed a similar approach in

\footnotetext{
159 Ibid., Articles 184-188.

160 See Prosecutor v. Nahimana et al., ICTR (Appeal Judgment of 28 November 2007), ICTR-99-52-A, paras. 1040-1043; Prosecutor v. Blaskić, ICTY (Judgment of 3 March 2000), IT-95-14-T, para. 807 .

161 On the application of absorption or addition in such cases, see Mekonnen Welelaw v. Federal Ethics and Anti-Corruption Commission Prosecutor, FsC Cassation Bench (Judgment of 26 June 2014), File no. 96503, pp. $2-4$.

162 See Penal Code of 1957, Article 81; FDRE Criminal Code Article 84.

163 See Mettraux, supra note 20, pp. 350-351.

164 For details, see T.S. Metekia, 'Violence against and using the Dead: Ethiopia's Dergue Cases', 4(1) Journal of Human Remains and Violence (2018) 86-87.
} 
relation to convicts who were found to have eaten the organs (kidneys and livers), drunk the blood, and butchered the genitals and elbows of their victims as a sign of superiority and victory. ${ }^{165}$ Likewise, the UNICTs have also noted that vicious circumstances of the commission constitute 'a decisive aggravating circumstance.' ${ }^{166}$

In pronouncing 18 death sentences in Mengistu et al., the FSC highlighted the abuse of a position of power in the sense that the defendants were members of the Dergue's Standing Committee, the regime's highest executive organ. ${ }^{167} \mathrm{~A}$ closer look at practice reveals that being the highest ranking or a low-ranking officer in the general military hierarchy or civilian structure did not make a difference for the assessment of the abuse of a position of power. It operated on the assumption that as any position of authority carries with it a duty to serve and protect others, the criminal must be subjected to a harsher sentence as long as he or she had a position of authority at the time of the commission of the crime. ${ }^{168}$

Nonetheless, the assumption can be set aside if it is shown that the perpetrator did not abuse her or his position of power. Judges may disregard the position of authority and instead mitigate the sentence on grounds such as obedience to a superior order, as was done by the FSC in Teshome Kebede et al., ${ }^{169}$ and by Amhara Supreme Court (ASC) in Demetse Gebremedehen et al. ${ }^{170}$ Interestingly, according to the judgment of Oromia Supreme Court (OsC) in Teshome Gobenea et al., even a regional governor can successfully invoke obedience to superior order (justified fear) as a mitigating factor. ${ }^{171}$ In this regard, Ethiopian practice appears to be more or less similar to the practice of the UNICTs and the ICC where the emphasis is not per se on a position of authority but on the abuse of that position. ${ }^{172}$

\footnotetext{
165 See supra note 11.

166 See Blaskić, supra note 164, para. 783. See also Prosecutor v. Kayishema and Ruzindana, ICTR (Sentencing Judgment of 21 May 1999), ICTR-95-1-T, para. 18.

167 See Mengistu Hailemariam et al., supra note 135, p. 95.

168 Aliyu Yesufe et al., supra note 11, p 5.

169 Teshome Kebede v. SPO, FSC (Appeal Judgment of 26 March 2002), File no. 6486, p. 6.

170 SPO v. Demetse Gebremedehen et al., ASC (Sentencing Judgment of 16 August 2005), File no. 1310, p. 7 .

171 Aman Gobena et al., supra note 46, pp. 7-9.

172 See Prosecutor v. Milan Babić, ICTy (Judgment on Sentencing Appeal of 18 July 2005), IT03-72-A, para. 80; Emmanuel Ndinddabahizi v. Prosecutor, ICTR (Appeal Judgment of 16
} 
An aggravating factor typical to the Ethiopian core crimes trials is the accused being an absconder. ${ }^{173}$ This has not been regarded as a ground of aggravation in international trials due to the unacceptability of trial in absentia before the UNICTs and the ICC. ${ }^{174}$ Even in Ethiopia, where trial in absentia is allowed as a last resort proceeding in relation to crimes punishable with rigorous imprisonment of 12 years and above, ${ }^{175}$ the sentencing law does not discriminate against a fugitive offender. Its qualification as an aggravating factor is, therefore, a result of judicial consideration which seems to have been prompted by the need to respond to the unprecedented proliferation of absence in the Dergue trials. Having tried 2188 of 5119 defendants in their absence, these trials have evidently struggled with the absence of defendants, perhaps, like no other trial of international crimes in history. ${ }^{176}$ As also noted in the war crimes case, in which presence at trial was regarded as a mitigating factor, judges opined that from the perspective of proportionality of punishment it would be unfair to punish the present and the absent alike. ${ }^{177}$

Notably, aggravation or mitigation of sentences on account of situationspecific factors is not unique to the Ethiopian trials. Similarly, the UNICTs have taken into account factors that have particular relevance to the situation in which they have been operating. For instance, voluntary surrender has been regarded by the ICTY as a mitigating factor owing to the challenges the tribunal had faced in relation to State cooperation. ${ }^{178}$

January 2007), ICTR-01-71-A, para. 136. See also Prosecutor v. Thomas Lubanga Dyilo, ICCAppeals Chamber (Judgment on the appeals of the Prosecutor and Mr Thomas Lubanga Dyilo against the 'Decision on Sentence Pursuant to Article 76 of the Statute' of 1 December 2014), ICC-01/04-01/o6 A4A6, para. 82.

173 See SPO v. Elias Tsegaye et al., FHC (Sentencing Judgment of 4 May 2001) File No. 632/89 p. 6; SPO v. Tafa Gurmu, FSC (Appeal Judgment of 19 April 2001) File No. 4896, p. 3.

174 For details regarding in/applicability of trial in absentia in the domain of international criminal justice, see Paola Gaeta, 'Trial In Absentia Before the Special Tribunal for Lebanon', in Amal Alamuddin et al. (eds.), The Special Tribunal for Lebanon: Law and Practice (Oxford University Press, Oxford, 2014) 232-238; William Schabas, 'In Absentia Proceedings before International Criminal Courts', in Göran Sluiter and Sergey Vasiliev (eds.), International Criminal Procedure: Towards a Coherent Body of Law (Cameron May, London, 2009) pp. 336-342.

175 See Criminal Procedure Code, Article 161.

${ }_{17} 6$ See 'Dem Yazele Dossie', supra note 12, p. 444.

177 See Legesse Asfaw et al., supra note 104, p. 7.

178 See Prosecutor v. Milan Simić, ICTY (Sentencing Judgment of 17 October 2002), IT-95-9/2-S, para. 107. 


\section{Multiplicity of Convicts and the Problem of Individualization of Punishment}

As noted at the outset of this article, core crimes trials in Ethiopia have been mass trials, with the exception of the Anuak-Nuwer trials where there were only 9 defendants. In the Dergue cases 5119 defendants were tried, while 276 defendants stood trial in the Oromo-Gumuz cases. Perhaps no other core crimes trial in history has prosecuted a comparable number of defendants as those prosecuted in Ethiopia, except for the case of Rwandan national courts and the Gacaca courts for genocide-related cases. ${ }^{179}$ The ICTY and ICTR have tried and punished, respectively, 90 and 62 individuals. ${ }^{180}$ The ICC has, so far, convicted only 7 defendants. ${ }^{181}$

Most importantly, there was rarely a trial of a single defendant in Ethiopia's core crime cases. The main genocide trial, Mengistu et al., had, initially, 106 co-defendants while 23 defendants stood trial in the war crimes case. Mekonnen Gelan et al. stands out as the single trial with the highest number of co-defendants, that is, 237. In the Oromo Gumuz trials, Tadesse Jewannie et al. and Aliyu Yesufe et al. had, respectively, 137 and 127 co-defendants.

The multiplicity of defendants, at times, created issues concerning the accused's right to defend oneself. In Mengistu et al., the FHC rejected the defendants' preliminary objection requesting a separate trial and asserted that the joinder of the defendants was justified as the manner of the commission of the crime involved all of them. ${ }^{182}$ The ultimate effect of the multiplicity of defendants was felt at the sentencing stage. Here, it tested the judges' willingness and ability to uphold the Criminal Code's principle of individualization of sentence and non-transmissibility of personal circumstances (Article 41) as well as the totality principle (Article 88(2)).

Several sentencing judgments failed to individualize the penalty by attributing personal circumstances collectively to several defendants. In Mengistu et al., for instance, mitigating factors such as illness, old age, service in

\footnotetext{
179 1,958,634 cases were tried through Gacaca courts. See http://gacaca.rw/about/achievements/, accessed 19 February 2018.

180 On the ICTY, see http://www.icty.org/sid/24, accessed 20 February 2018; on the ICTR, see http://unictr.unmict.org/en/tribunal, accessed 20 February 2018.

181 See https://www.icc-cpi.int/Pages/defendants-wip.aspx, accessed 8 June 2018.

182 See Mengistu Hailmariam et al., supra note 75 (Ruling on Defendants' Preliminary Objections, 1 November 1994) p. 206.
} 
peacekeeping missions, were applied collectively to all defendants. ${ }^{183}$ In $\mathrm{Me}$ konnen Gelan et al., several defendants were sentenced to identical penalties because they were either young students or uneducated peasants. ${ }^{184}$ In these and several other cases, the courts neither considered the personal circumstances of the defendants separately nor discussed the level of participation of each convict.

In other cases, personal circumstances were ignored altogether as sentencing judgments were limited to mentioning just the gravity of the crime, albeit that they do not even explicitly state its actual gravity and its implication for the determination of sentence, as discussed above. ${ }^{185}$ In Aliyu Yesufe et al., 17 convicts were condemned collectively to 15 years of rigorous imprisonment on the ground that they participated in the killing of 4 individuals. ${ }^{186}$ In Tadesse Jewannie et al., 27 defendants were sentenced to 20 years because, according to the court, 'they killed one person each.' ${ }^{187}$ In Brigadier General Tedla Desta et al., 11 defendants were sentenced to 9 years of rigorous imprisonment based on the common ground that they all participated in the unlawful arrest of several young persons. ${ }^{188}$

Notwithstanding, the Ethiopian courts have, like their international counterparts, ${ }^{189}$ often highlighted the need to individualize sentence and respect the totality principle. In that regard, virtually all sentencing judgments in Ethiopia recite that the sentence shall be calculated in compliance with Articles 41 and 88 of the Criminal Code. It, thus, appears that there were just too many defendants in one trial to treat each of them separately and methodically. One might, therefore, need to consider the unique challenge that the Ethiopian courts had to deal with while comparing them to the UNICTs and the ICC, where not more than, respectively, 7 and 5 defendants were tried in a single trial. ${ }^{190}$

\footnotetext{
183 Ibid.

184 Mekonnen Gelan, supra note 127, pp. 312-314.

185 See supra Section 3.1.

186 Aliyu Yesufe et al., supra note 11, pp. 3-4.

187 Tadesse Jewannie et al., supra note 11, pp. 1-14.

188 SPO v. Brigadier General Tedla Desta et al., OsC (Judgment of 13 May 2001) File no. 24/92, p. 144.

189 For the UNICTs' practice concerning the totality principle and individualization of sentences, see Mettraux, supra note 21, pp. 355-357.

190 See Prosecutor v. Popović et al., ICTY (Judgment of 10 June 2010) IT-05-88-T; Prosecutor v. Bemba et al., ICC (Judgment of 22 March 2017) ICC-01/05-01/13.
} 
This article has discussed the general and significant rules governing sentencing determination in Ethiopia in the context of the core crimes of genocide and war crimes. It has analysed this law and practice in light of and in comparison to the law and practice of the UNICTs and the ICC. It has also discussed the punishment of core crimes in comparison with that of domestic crimes, not least concerning applicable penalties and sentencing rationales.

The article has revealed the absence in Ethiopian law of a penalty scheme that takes into account the nature and gravity of core crimes, because of which some domestic crimes are punishable, paradoxically, more severely than core crimes. It has also pointed out several differences in the applicable penalties available to Ethiopian law, the UNICTs, and the ICc. The applicability of the death penalty in Ethiopia represents the most significant difference. Some of the differences are understandable in the sense that municipal laws (including those of states parties to the ICC) are not required to apply international penalties, ${ }^{191}$ although international law strives to minimise the difference by employing approaches such as the progressive abolition of the death penalty. ${ }^{192}$

According to this article's findings, nowhere in their judgments have the Ethiopian courts explained and analysed the sentencing rationales they invoked. While the UNICTs and the ICC have attempted to justify the punishment of core crimes by giving due regard to their distinct nature, Ethiopian courts, by contrast, have employed sentencing rationales in a manner that is typical to the punishment of domestic crimes. This deficit may find an explanation in the fact that Ethiopian judges lack expertise in the evolving field of international criminal law, a problem that has been identified as one of the shortcomings of national prosecutions of core crimes in general. ${ }^{193}$

The article has found that both Ethiopian and international sentencing practices lack transparency. To a certain degree, the exercise of broad judicial

191 See Róisín Mulgrew, Towards the Development of the International Penal System (Cambridge University Press, Cambridge, 2013) pp. 13-14.

192 See for details, Christof Heyns et al., "The Right to Life and the Progressive Abolition of the Death Penalty', in Margaret deGuzman and Diane Amann (eds.), Arcs of Global Justice: Essays in Honour of William A. Schabas (Oxford University Press, Oxford, 2018) pp. 127-134.

193 See Antonio Cassese, 'The Italian Court of Cassation Misapprehends the Notion of War Crimes: The Lozano Case', 6(1) Journal of International Criminal Justice (2008) 1084-1087; Robert Cryer et al., Introduction to International Criminal Law and Procedure $\left(2^{\text {nd }}\right.$ ed., Cambridge University Press, Cambridge, 2010) p. 35. 
discretion by both international and domestic courts has contributed to the lack of transparency in sentencing. However, the opacity of Ethiopian sentencing judgments has created further difficulties for verifying double counting errors. As shown in this article, the difference in the scope of discretion between international and Ethiopian judges explains most of the differences between the two sentencing systems, in particular with regards to the application of aggravating and mitigating factors. Nonetheless, there are also cases in which Ethiopian courts have imposed more severe or lenient penalties by misapplying aggravating and mitigating factors.

Finally, this article has shown that there is in principle no noticeable difference between the Ethiopian and the international system as to the need to individualize sentences and comply with the totality principle. Ethiopian practice is however significantly deficient in this regard. This could be because Ethiopian courts had to deal with the unique challenge of punishing an unmanageable number of defendants in a single trial. 